Prepared for the U.S. Department of Energy

under Contract DE-AC05-76RL01830

\title{
Contaminants of the Bismuth Phosphate Process as Signifiers of Nuclear Reprocessing History
}

\section{FY-2010 Final Report}

\begin{abstract}
JM Schwantes
LE Sweet
\end{abstract}

October 2011 


\title{
DISCLAIMER
}

This report was prepared as an account of work sponsored by an agency of the United States Government. Neither the United States Government nor any agency thereof, nor Battelle Memorial Institute, nor any of their employees, makes any warranty, express or implied, or assumes any legal liability or responsibility for the accuracy, completeness, or usefulness of any information, apparatus, product, or process disclosed, or represents that its use would not infringe privately owned rights. Reference herein to any specific commercial product, process, or service by trade name, trademark, manufacturer, or otherwise does not necessarily constitute or imply its endorsement, recommendation, or favoring by the United States Government or any agency thereof, or Battelle Memorial Institute. The views and opinions of authors expressed herein do not necessarily state or reflect those of the United States Government or any agency thereof.

\author{
PACIFIC NORTHWEST NATIONAL LABORATORY \\ operated by \\ BATTELLE \\ for the \\ UNITED STATES DEPARTMENT OF ENERGY \\ under Contract DE-AC05-76RL01830
}

Printed in the United States of America
Available to DOE and DOE contractors from the Office of Scientific and Technical Information,
P.O. Box 62, Oak Ridge, TN 37831-0062;
ph: (865) 576-8401
fax: $(865)$ 576-5728
email: reports@adonis.osti.gov

\begin{abstract}
Available to the public from the National Technical Information Service, U.S. Department of Commerce, 5285 Port Royal Rd., Springfield, VA 22161 ph: (800) 553-6847 fax: $(703) 605-6900$ email: orders@ntis.fedworld.gov online ordering: http://www.ntis.gov/ordering.htm
\end{abstract}

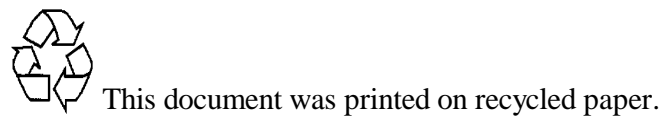




\section{Contaminants of the Bismuth Phosphate Process as Signifiers of Nuclear Reprocessing History}

\section{FY-2010 Final Report}

JM Schwantes

LE Sweet

October 2011

Prepared for the U.S. Department of Energy

under Contract DE-AC05-76RL01830

Pacific Northwest National Laboratory

Richland, Washington 99352 


\title{
CONTAMINANTS OF THE BISMUTH PHOSPHATE PROCESS AS SIGNIFIERS OF NUCLEAR REPROCESSING HISTORY
}

\author{
Jon M. Schwantes and Luke Sweet
}

Pacific Northwest National Laboratory, PO Box 999, Richland, WA, 99352

Tel: (509) 375-7378, Email: Jon.Schwantes@pnnl.gov

\begin{abstract}
Reagents used in spent nuclear fuel recycling impart unique contaminant patterns into the product stream of the process. Efforts are underway at Pacific Northwest National Laboratory to characterize and understand the relationship between these patterns and the process that created them. A main challenge to this effort, recycling processes that were employed at the Hanford site from 1944-1989 have been retired for decades. This precludes direct measurements of the contaminant patterns that propagate within product streams of these facilities. In the absence of any operating recycling facilities at Hanford, we have taken a multipronged approach to cataloging contaminants of U.S. reprocessing activities using: (1) historical records summarizing contaminants within the final $\mathrm{Pu}$ metal button product of these facilities; (2) samples of opportunity that represent intermediate products of these processes; and (3) lab-scale experiments and model simulations designed to replicate contaminant patterns at each stage of nuclear fuel reprocessing. This report provides a summary of the progress and results from Fiscal Year (April 1, 2010 - September 30, 2011) 2010.
\end{abstract}

\section{INTRODUCTION}

The Hanford Site in Washington became the location for U.S. plutonium production during World War II. The Pu produced at this site was used in "Trinity" and "Fat Man", the name given to the world's first test of a nuclear weapon in April 1945, and the first Pu nuclear weapon used in combat dropped on Nagasaki, Japan on August 10, 1945. Plutonium production and reprocessing continued at the Hanford site through 1989, culminating in the production of roughly two-thirds of the U.S. weapons stockpile of $\mathrm{Pu}$. The remaining one-third of the stockpile was produced at the Savannah River Site between 1953-1992[1]. Efforts described here are focused on categorizing intermediate and final contaminant patterns in the Pu product stream of past reprocessing activities at the Hanford site.

From 1944 through the mid 1980's a total of nine light water cooled, graphite moderated, reactors operated at the Hanford nuclear reservation, producing a total of $67 \mathrm{MT}$ of Pu for the U.S. Pu stockpile[1]. These reactors burned a variety of natural, depleted, enriched and recycled U fuels. Spent fuel was reprocessed using one of three main methods including, the Bismuth Phosphate method (1944-1956), the REDOX or Hexone method (1952-1965), and the PUREX method (1956-1989). In addition to reprocessing, Pu metal reduction was also carried out at Hanford's Plutonium Finishing Plant from 1949 through the early 1990's, resulting in the production of $\sim 2 \mathrm{~kg}$ plutonium metal "Buttons". Previous efforts (Schwantes et al., 2010) identified high $\mathrm{Al}$ concentrations within buttons produced in 1955 and 1956 and attributed this to the addition of $\mathrm{Al}\left(\mathrm{NO}_{3}\right)_{3}$ during reprocessing. The identification of a reagent within the product stream after reprocessing, chemical conversion, and metal reduction exemplifies the refractory nature of reagents and their potential usefulness as signifiers of process history. 


\section{$\underline{\text { BACKGROUND }}$}

\section{Bismuth Phosphate}

The Bismuth Phosphate reprocessing method was the world's first industrial-scale reprocessing method. This method was based upon a series of precipitations and solid-liquid phase separations in order to separate $\mathrm{Pu}$ from spent nuclear fuel components. Briefly, spent fuel was dissolved in nitric acid. Uranium ions were stabilized in solution with the addition of sulfate, while $\mathrm{Pu}$ was reduced and co-precipitated with the fission products (predominantly lanthanides) away from the $\mathrm{U}$ using bismuth phosphate. After phase separation and dissolution of the solid phase product, $\mathrm{Pu}$ is stabilized in solution by oxidation while the fission products are again precipitated with bismuth phosphate. This cycle of reduction, precipitation, phase separation, dissolution and oxidation are repeated several times to enhance the effectiveness of separation. In the final cycles of the separation method, the more effective, but also more corrosive compound, lanthanum fluoride, is used in place of bismuth phosphate as the co-precipitate of choice. 


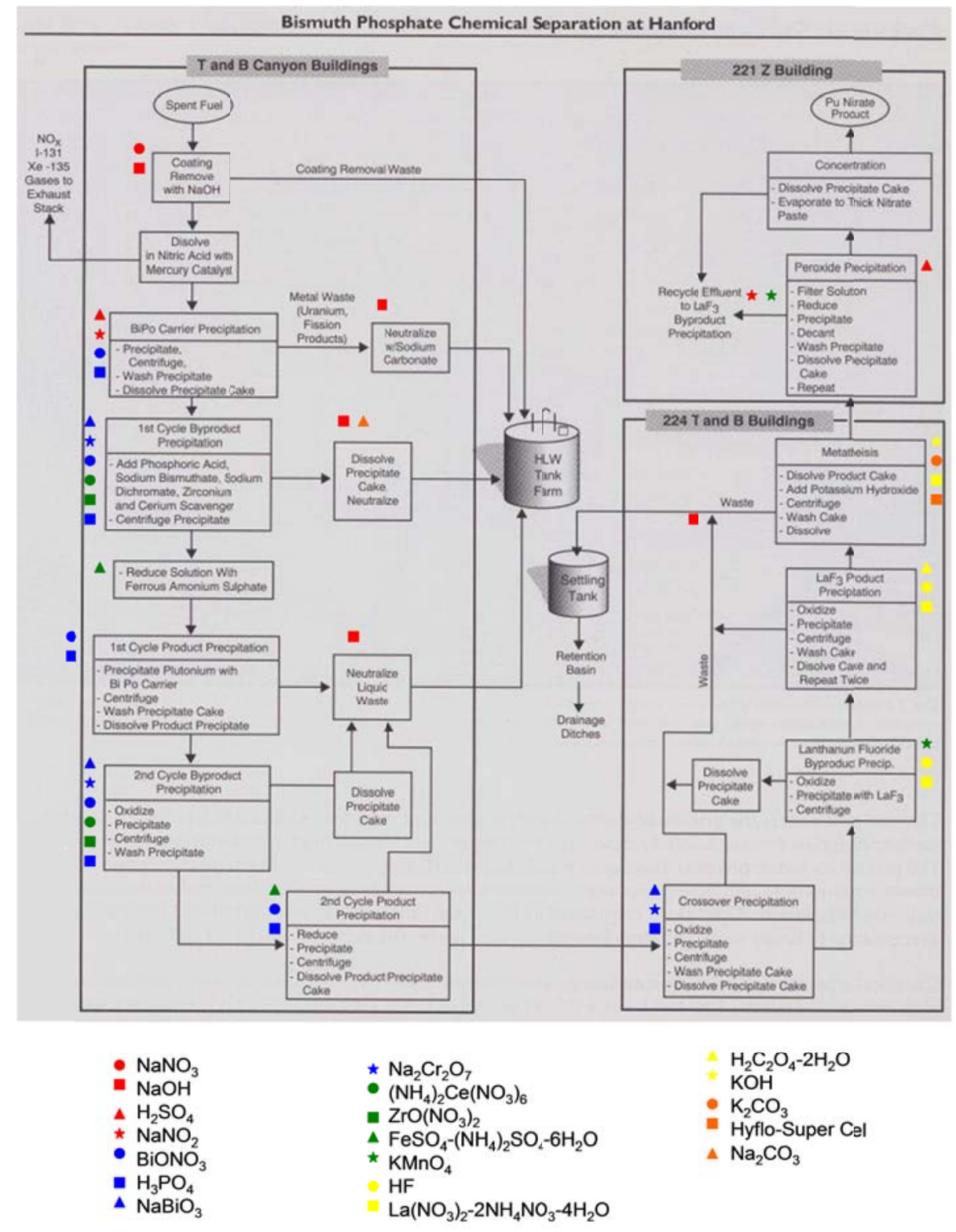

Figure 1. Flow sheet of the Bismuth Phosphate reprocessing method (augmented from [2]). Symbols indicate the types and locations within the process where reagents are added.

\section{EXPERIMENTAL PROCEDURE}

\section{Lab-scale Replication of the Bismuth Phosphate Process}

Laboratory scale experiments are being conducted to replicate the industrial scale process of extracting $\mathrm{Pu}$ from a solution of concentrated uranium (U) from spent fuel by the method known as the Bismuth Phosphate process. A laboratory method was developed by scaling down ( 600,000 fold) the 1944 industrial process used at the Hanford site, as described in a historical document[3]. Laboratory experiments used gamma-emitting isotopes as tracers of process reagents to measure the fate of constituents during chemical separations. Gamma energy analysis (GEA) was used to quantify isotopes of the alkali metals and lanthanides and $U$ 
during the separations. The fate of $U$ was followed by measuring gamma emission from ${ }^{235} \mathrm{U}$ present within our experiments at natural abundance.

The fission product concentration listed on pg 130 of Hanford document HW-10475C was used to determine the concentration of $\mathrm{Cs}$ and lanthanide fission products that were present in the uranyl nitrate hexahydrate $(\mathrm{UNH})$ solution that was sent through the separations process. Eu was used to represent all the lanthanides in the UNH metal solution. The composition of the UNH solution used on the lab scale experiments is shown in Table 1. Non-rad Eu and Cs were added in the forms of aqueous $\mathrm{Eu}\left(\mathrm{NO}_{3}\right)_{3}$ and $\mathrm{Cs}\left(\mathrm{NO}_{3}\right)$ to give the solution the correct concentration of $\mathrm{Cs}$ and lanthanides without adding the activity associated with ${ }^{152} \mathrm{Eu}$ and ${ }^{134} \mathrm{Cs}$. The fate of $\mathrm{Na}^{+}$from reagents was traced using ${ }^{22} \mathrm{Na}$. ${ }^{207} \mathrm{Bi}$ was added to trace the fate of the bismuth reagents used throughout the process. The goal is to get accurate numbers for the partitioning coefficients for the first precipitation step in the bismuth phosphate process.

$\begin{aligned} & \text { Table 1. Lab scale representation of the UNH meal solution described as the end product of } \\
& \text { section } 3 \text { and } 4 \text { of the bismuth phosphate process described in DUH-1687 }\end{aligned}$
\begin{tabular}{|l|r|r|}
\hline Reagent & $\begin{array}{l}\text { Weight in original document } \\
(\mathrm{lb})\end{array}$ & Mass used for lab scale (g) \\
\hline $\mathrm{HNO}_{3}$ & 232 & 0.1700 \\
\hline $\mathrm{UO}_{2}\left(\mathrm{NO}_{3}\right)_{2} \bullet 6 \mathrm{H}_{2} \mathrm{O}$ & 4640 & 3.40026 \\
\hline $\mathrm{H}_{2} \mathrm{O}$ & 6823 & 4.93200 \\
\hline Eu as $\left(\mathrm{Eu}\left(\mathrm{NO}_{3}\right)_{3}\right)$ & 0.13580 & $9.952 \mathrm{E}-05$ \\
\hline $\mathrm{Cs}$ as $\left(\mathrm{Cs}\left(\mathrm{NO}_{3}\right)\right)$ & 0.06376 & $4.673 \mathrm{E}-05$ \\
\hline
\end{tabular}

\section{Section 8 "Product Extraction" of The Bismuth Phosphate Process Executed On Lab Scale}

The summary of the lab scale execution of the "Product Extraction" step in the bismuth phosphate process is summarized in Tables 2-11. This process was scaled down by a factor of $1.84 \times 10^{-7}$. Tables $2,4,6,8$ and 10 show the quantities reported in the full scale process and the quantities used in the lab scale process.

Section 8B, the Filtration and wash step of the "Product Extraction" section, was modified slightly (by the use of a filter syringe) to better represent the solution extraction that can occur on the full scale process. The solution was centrifuged at $900 \mathrm{rpm}$ for 5 minutes. The supernate was pipette off and added to a $0.2 \mu \mathrm{m}$ pore size filter syringe. The remaining cake was washed with $1 \mathrm{~mL}$ of $\mathrm{H}_{2} \mathrm{O}$ and then centrifuged again at $900 \mathrm{rpm}$ for 5 minutes. The wash $\mathrm{H}_{2} \mathrm{O}$ was pipetted off and added to the same filter syringe that contains the supernate. The cake was washed two more times using this method. The supernate/wash solution was then filtered through the $0.2 \mu \mathrm{m}$ pore size filter into a $20 \mathrm{~mL}$ scintillation vial. The syringe and filter were washed with $\mathrm{H}_{2} \mathrm{O}$ two times. The filter syringe washes where added to the supernate wash solution. $500 \mu \mathrm{L}$ of $18 \mathrm{M} \mathrm{HNO}_{3}$ was added to the liquid fraction to keep every thing dissolved after dilution. The liquid fraction was diluted until the total mass of the solution equaled $10 \mathrm{~g}$. This liquid fration was labeled and sent for counting.

The cake was dissolved with $8 \mathrm{M} \mathrm{HNO}_{3}$ and transferred to a $20 \mathrm{~mL}$ scintillation vial. The centrifuge tube that contained the cake was washed three times with $8 \mathrm{M} \mathrm{HNO}$. These $\mathrm{HNO}_{3}$ washes were combined with the dissolved cake in a $20 \mathrm{~mL}$ scintillation vial. The total mass 
was adjusted to $10 \mathrm{~g}$ with $\mathrm{H}_{2} \mathrm{O}$. A schematic of the "Product Extraction" section of the Bismuth Phosphate process is shown in Figure 2.

Gama spectra of the three solutions collected (solution before adding $\mathrm{H}_{3} \mathrm{PO}_{4}$, solution containing supernate after adding $\mathrm{H}_{3} \mathrm{PO}_{4}$ and the dissolved cake solution) were taken using a germanium gamma detector. These spectra were used to quantify the contents of each of the solutions. Since the mass of the fraction collected before $\mathrm{H}_{3} \mathrm{PO}_{4}$ was added is less than half the remaining fraction for precipitation, the fractions were normalized so that activities obtained from counting were directly comparable. The normalized activity in the solution before $\mathrm{H}_{3} \mathrm{PO}_{4}$ was added was regarded as the total activity added. The activity of the supernate solution after $\mathrm{H}_{3} \mathrm{PO}_{4}$ was added was divided by the total activity (activity before $\mathrm{H}_{3} \mathrm{PO}_{4}$ ) to get the percentage of tracer in supernate. The activity of the cake was divided by the total activity (activity before $\mathrm{H}_{3} \mathrm{PO}_{4}$ ) to get the percentage of tracer in the cake.

Vials, file names and counting results are labeled with the notebook page the run was started, the LRB \#60155 and the corresponding fraction. The notebook page runs were started on sectioned off bellow. 


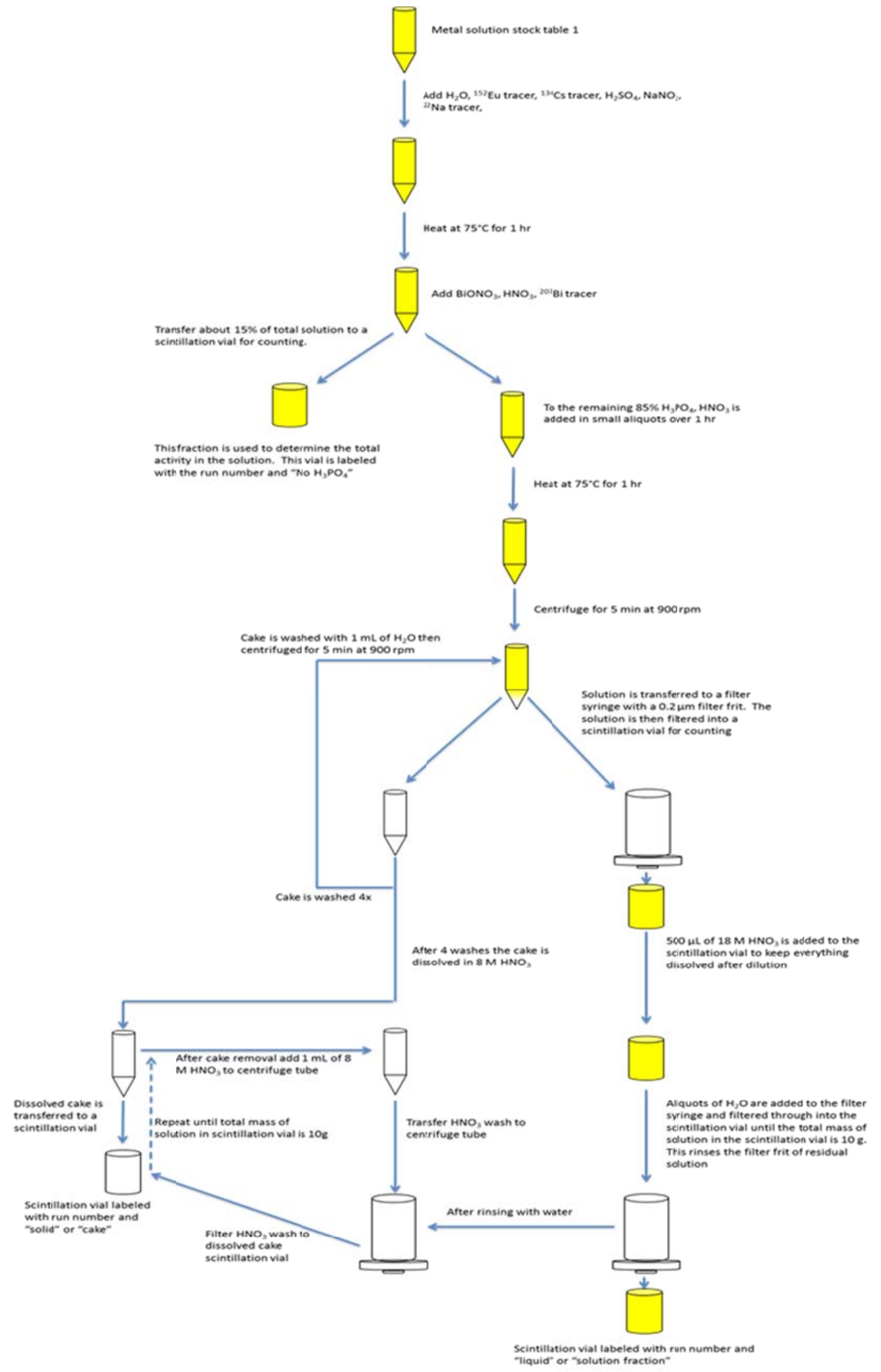

Figure 2. Schematic of Section 8 "Product Extraction" of the Bismuth Phosphate process at a lab scale. 


\section{RESULTS \& DISCUSSION}

Run on pg 92 of LRB 60155

Several runs where made with ${ }^{207} \mathrm{Bi}$ as the only tracer. These runs were used to fine-tune the procedure shown in the schematic of Figure 1. The last of these runs is summarized in the tables below.

\begin{tabular}{|c|c|c|}
\hline Reagent & $\begin{array}{l}\text { Weight in } \\
\text { original } \\
\text { document (lb) }\end{array}$ & $\begin{array}{l}\text { Mass or activity } \\
\text { used for lab scale }\end{array}$ \\
\hline UNH (stock Table 1) & 11960 & $1.00087 \mathrm{~g}$ \\
\hline $\mathrm{H}_{2} \mathrm{O}$ & 7417 & $0.62045 \mathrm{~g}$ \\
\hline $\mathrm{H}_{2} \mathrm{SO}_{4} 93 \%$ & 1018 & $0.08549 \mathrm{~g}$ \\
\hline $\mathrm{NaNO}_{2} 14 \%$ & 953 & $0.07690 \mathrm{~g}$ \\
\hline \multicolumn{3}{|l|}{$\begin{array}{l}\text { Heat solution to } 75^{\circ} \mathrm{C} \text { for } 1 \\
\text { hour }\end{array}$} \\
\hline $\mathrm{BiONO}_{3} 24 \%, \mathrm{HNO}_{3} 19 \%$ & 277 & $0.23490 \mathrm{~g}$ \\
\hline $\mathrm{Bi}-207$ tracer & & $8.61 \mathrm{E}-5 \mathrm{Ci}$ \\
\hline \multicolumn{3}{|l|}{$\begin{array}{l}\text { Sample split }-0.36008 \mathrm{~g} \text { saved } \\
\text { for counting }-1.90014 \mathrm{~g} \text { taken } \\
\text { for phosphate precipitation }\end{array}$} \\
\hline $\mathrm{H}_{3} \mathrm{PO}_{4} 73.5 \%, \mathrm{HNO}_{3} 1.2 \%$ & 1575 & $0.13749 \mathrm{~g}$ \\
\hline $\begin{array}{l}\text { Heat solution to } 75^{\circ} \mathrm{C} \text { for } 1 \\
\text { hour }\end{array}$ & & \\
\hline
\end{tabular}

Table 3. Distribution of tracers in after completing section 8 - Product Precipitation in the bismuth phosphate process outlined in DUH-1687. Errors from the counting measurements in parentheses. The errors in the counting measurements are indicated in parenthesis.

\begin{tabular}{|c|c|c|}
\hline Isotope & $\%$ in cake & $\begin{array}{l}\text { \% left in solution after } \\
\text { precipitation }\end{array}$ \\
\hline${ }^{207} \mathrm{Bi}$ & $98.14( \pm 4.61)$ & $1.95 \%$ (MDA) \\
\hline
\end{tabular}

Much more ${ }^{207} \mathrm{Bi}$ tracer had to be used in order to detect the $\mathrm{Bi}$ in each of the fractions. Since the $\mathrm{Bi}$ tracer was in a $\mathrm{HCl}$ solution and $\mathrm{HCl}$ is not in the process the solution was converted to a $\mathrm{HNO}_{3}$ solution by heating in concentrated $\mathrm{HNO}_{3}$.

Run on pg 98 of LRB 60155

Results from the first execution of the "Product Extraction" section of the Bismuth Phosphate process is shown in tables 4 and 5. This run contained the tracers ${ }^{152} \mathrm{Eu},{ }^{134} \mathrm{Cs},{ }^{22} \mathrm{Na}$ and ${ }^{207} \mathrm{Bi}$. The only other radioactive material added was depleted $U$ from the uranyl nitrate solution. The counting results are shown in table 5 . 


\begin{tabular}{|l|l|r|}
\hline $\begin{array}{l}\text { Table 4. Summary of section 8A Product extraction -precipitation for } \\
\text { run labeled pg } 98 \text { of LRB 60155 }\end{array}$ & $\begin{array}{l}\text { Weight in } \\
\text { original } \\
\text { document (lb) }\end{array}$ & $\begin{array}{l}\text { Mass or activity } \\
\text { used for lab scale }\end{array}$ \\
\hline Reagent & 11960 & $1.00148 \mathrm{~g}$ \\
\hline $\mathrm{UNH}$ (stock Table 1) & 7417 & $0.61963 \mathrm{~g}$ \\
\hline $\mathrm{H}_{2} \mathrm{O}$ & & $0.3500 \mu \mathrm{Ci}$ \\
\hline Eu-152 tracer & & $0.2083 \mu \mathrm{Ci}$ \\
\hline $\mathrm{Cs}-134$ tracer & 1018 & $0.10960 \mathrm{~g}$ \\
\hline $\mathrm{H}_{2} \mathrm{SO}_{4} 93 \%$ & 953 & $0.07790 \mathrm{~g}$ \\
\hline $\mathrm{NaNO}_{2} 14 \%$ & & $0.2375 \mu \mathrm{Ci}$ \\
\hline $\mathrm{Na}_{2} 22$ tracer & & \\
\hline $\begin{array}{l}\mathrm{Heat} \text { solution to } 75^{\circ} \mathrm{C} \text { for } 1 \\
\text { hour }\end{array}$ & & $0.24730 \mathrm{~g}$ \\
\hline $\mathrm{BiONO} \mathrm{O}_{3} 24 \%, \mathrm{HNO}_{3} 19 \%$ & 277 & \\
\hline $\mathrm{Bi}-207$ tracer & & \\
\hline $\begin{array}{l}\mathrm{Sample} \text { split }-0.36008 \mathrm{~g} \text { saved } \\
\text { for counting }-1.90014 \mathrm{~g} \text { taken } \\
\text { for phosphate } \mathrm{precipitation}^{2}\end{array}$ & & \\
\hline $\mathrm{H}_{3} \mathrm{PO}_{4} 73.5 \%, \mathrm{HNO}_{3} 1.2 \%$ & & \\
\hline $\begin{array}{l}\mathrm{Heat} \text { solution to } 75^{\circ} \mathrm{C} \text { for } 1 \\
\text { hour }\end{array}$ & & \\
\hline
\end{tabular}

Table 5. Distribution of tracers in after completing section 8 - Product Precipitation in the bismuth phosphate process outlined in DUH-1687. Errors from the counting measurements in parentheses.

\begin{tabular}{|c|c|c|}
\hline Isotope & $\%$ in cake & $\begin{array}{l}\text { \% left in solution after } \\
\text { precipitation }\end{array}$ \\
\hline${ }^{22} \mathrm{Na}$ & $3.55( \pm 0.137)$ & $95.10( \pm 3.79)$ \\
\hline${ }^{134} \mathrm{Cs}$ & $0.42( \pm 0.018)$ & $115.38( \pm 3.29)$ \\
\hline${ }^{207} \mathrm{Bi}$ & $93.82( \pm 5.45)$ & $2.64( \pm 0.404)$ \\
\hline${ }^{152} \mathrm{Eu}$ & $45.71( \pm 1.04)$ & $53.31( \pm 1.25)$ \\
\hline
\end{tabular}

Since two different counting experiments were done to determine the activity in the cake and the activity left in solution, the difference between the sum of the two activities for a given nuclide and $100 \%$ indicates the error in the experiment. One source of error may be in the less than perfect separation of the supernate solution from the cake after precipitation. An indicator of this error is that activity from ${ }^{207} \mathrm{Bi}$ was detected in the syringe filter after filtration. Since this activity is small and there is not a calibrated geometry of the syringe filter quantities of tracers left in the syringe filter could not be obtained. The error in the ${ }^{134} \mathrm{Cs}$ activity is not explained by Cs getting stuck in the syringe filter.

\section{Run on pg 105-1 of LRB 60155}

For these next few runs ${ }^{239} \mathrm{Pu}$ was added in concentrations of $250 \mathrm{~g}$ per metric ton of uranium $(250 \mathrm{ppm})$. This is roughly the concentration of $\mathrm{Pu}$ in the eradiated fuel rods used in this 
process according to $\mathrm{HW}-10475 \mathrm{C}$ pg 1 . For $1 \mathrm{~g}$ of stock UNH solution (table 1) there was $0.18954 \mathrm{~g}$ of uranium. To get the $\mathrm{U} / \mathrm{Pu}$ ratio to match that reported for the Hanford process $4.73910 \times 10^{-5} \mathrm{~g}(2.9 \mu \mathrm{Ci})$ of ${ }^{239} \mathrm{Pu}$ was added. The ${ }^{239} \mathrm{Pu}$ stock solution contained $1.07 \times 10^{-3} \mathrm{~g}$ of ${ }^{241} \mathrm{Pu}$ per gram of ${ }^{239} \mathrm{Pu}$ and $7.66 \times 10^{-4} \mathrm{~g}$ of ${ }^{241} \mathrm{Am}$ per gram of ${ }^{239} \mathrm{Pu}$.

Run on 105-2 of LRD 60155

Table 6. Summary of section 8A Product extraction -precipitation for run labeled pg 105-2 of LRB 60155

\begin{tabular}{|l|r|r|}
\hline Reagent & $\begin{array}{l}\text { Weight in } \\
\text { original } \\
\text { document (lb) }\end{array}$ & $\begin{array}{l}\text { Mass or activity } \\
\text { used for lab scale }\end{array}$ \\
\hline UNH (stock Table 1) & 11960 & $1.00244 \mathrm{~g}$ \\
\hline $\mathrm{H}_{2} \mathrm{O}$ & 7417 & $0.61461 \mathrm{~g}$ \\
\hline Eu-152 tracer & & $0.339 \mu \mathrm{Ci}$ \\
\hline $\mathrm{Cs}-134$ tracer & & $0.194 \mu \mathrm{Ci}$ \\
\hline $\mathrm{Pu}-239$ & 1018 & $0.11008 \mathrm{~g}$ \\
\hline $\mathrm{H}_{2} \mathrm{SO}_{4} 93 \%$ & 953 & $0.0822 \mathrm{~g}$ \\
\hline $\mathrm{NaNO} \mathrm{N}_{2} 14 \%$ & & $0.233 \mu \mathrm{Ci}$ \\
\hline $\mathrm{Na}-22$ tracer & & \\
\hline $\begin{array}{l}\mathrm{Heat} \text { solution to } 75^{\circ} \mathrm{C} \text { for } 1 \\
\text { hour }\end{array}$ & 277 & $0.02565 \mathrm{~g}$ \\
\hline $\mathrm{BiONO} \mathrm{O}_{3} 24 \%, \mathrm{HNO}_{3} 19 \%$ & 1575 & $0.0108 \mu \mathrm{Ci}$ \\
\hline $\mathrm{Bi}-207$ tracer & & $0.13694 \mathrm{~g}$ \\
\hline $\mathrm{H}_{3} \mathrm{PO}_{4} 73.5 \%, \mathrm{HNO}_{3} 1.2 \%$ & & \\
\hline $\begin{array}{l}\mathrm{Heat} \text { solution to } 75^{\circ} \mathrm{C} \text { for } 1 \\
\text { hour }\end{array}$ & & \\
\hline
\end{tabular}


Table 7. Results from gamma spectroscopy of the three fractions collected from the run of section 8 started on pg 105-2 of LRB 60155. The errors in the counting measurements are indicated in parenthesis.

\begin{tabular}{|c|c|c|}
\hline Isotope & $\%$ in cake & $\begin{array}{l}\text { \% left in solution after } \\
\text { precipitation }\end{array}$ \\
\hline${ }^{22} \mathrm{Na}$ & $1.032( \pm 0.042)$ & $90.395( \pm 3.598)$ \\
\hline${ }^{134} \mathrm{Cs}$ & $1.542( \pm 0.056)$ & $88.850( \pm 2.692)$ \\
\hline${ }^{207} \mathrm{Bi}$ & $86.048( \pm 5.283)$ & $6.569( \pm 1.356)$ \\
\hline${ }^{152} \mathrm{Eu}$ & $4.295( \pm 0.102)$ & $85.228( \pm 2.011)$ \\
\hline${ }^{239} \mathrm{Pu}$ & Not detected & Not detected \\
\hline${ }^{241} \mathrm{Am}$ & Not detected & $77.710( \pm 8.268)$ \\
\hline${ }^{235} \mathrm{U}$ & 1.614 (MDA) & $81.434(16.670)$ \\
\hline
\end{tabular}

${ }^{239} \mathrm{Pu}$ was probably not detected because it is a weak gamma emitter. The gamma signal/Compton scattering from the other tracers in solution probably swamped out any signal coming from ${ }^{239} \mathrm{Pu}$.

Run on pg 110 of LRB 60155

Table 8. Summary of section $8 \mathrm{~A}$ Product extraction -precipitation for run labeled pg 110 of LRB 60155

\begin{tabular}{|c|c|c|}
\hline Reagent & $\begin{array}{l}\text { Weight in } \\
\text { original } \\
\text { document (lb) }\end{array}$ & $\begin{array}{l}\text { Mass or activity } \\
\text { used for lab scale }\end{array}$ \\
\hline UNH (stock Table 1) & 11960 & $1.00432 \mathrm{~g}$ \\
\hline $\mathrm{H}_{2} \mathrm{O}$ & 7417 & $0.62022 \mathrm{~g}$ \\
\hline Pu-239 & & $\sim 2.91 \mu \mathrm{Ci}$ \\
\hline $\mathrm{H}_{2} \mathrm{SO}_{4} 93 \%$ & 1018 & $0.10325 \mathrm{~g}$ \\
\hline $\mathrm{NaNO}_{2} 14 \%$ & 953 & $0.07946 \mathrm{~g}$ \\
\hline $\begin{array}{l}\text { Heat solution to } 75^{\circ} \mathrm{C} \text { for } 1 \\
\text { hour }\end{array}$ & & \\
\hline $\mathrm{BiONO}_{3} 24 \%, \mathrm{HNO}_{3} 19 \%$ & 277 & $0.02549 \mathrm{~g}$ \\
\hline $\begin{array}{l}\text { Sample split }-0.36008 \mathrm{~g} \text { saved } \\
\text { for counting }-1.90014 \mathrm{~g} \text { taken } \\
\text { for phosphate precipitation }\end{array}$ & & \\
\hline $\mathrm{H}_{3} \mathrm{PO}_{4} 73.5 \%, \mathrm{HNO}_{3} 1.2 \%$ & 1575 & $0.13710 \mathrm{~g}$ \\
\hline $\begin{array}{l}\text { Heat solution to } 75^{\circ} \mathrm{C} \text { for } 1 \\
\text { hour }\end{array}$ & & \\
\hline
\end{tabular}

This run was not executed like the previous runs. Fractions for counting, in this instance, were not collected before precipitation. As such, the percent in cake and in solution were not independently verified. 
Table 9. Results from gamma spectroscopy of the three fractions collected from the run of section 8 started on pg 110 of LRB 60155. The \% errors in the counting measurements are indicated in parenthesis.

\begin{tabular}{|c|c|c|}
\hline Isotope & $\%$ in cake & $\begin{array}{l}\text { \% left in solution after } \\
\text { precipitation }\end{array}$ \\
\hline${ }^{239} \mathrm{Pu}$ & $90.862(3.02)$ & $9.138(50.84)$ \\
\hline${ }^{241} \mathrm{Am}$ & $8.508(4.41)$ & $91.492(4.17)$ \\
\hline${ }^{235} \mathrm{U}$ & $0.826(21.62)$ & $99.174(3.30)$ \\
\hline
\end{tabular}

Summary of Lab Scale runs of Sections 12 "Preparation For First By-Product Precipitation" and 13 "First By-Product Precipitation"

A lab scale execution of sections 12 "Preparation For First By-Product Precipitation" and 13 "First By-Product Precipitation" were carried out using the same concentration of ${ }^{239} \mathrm{Pu}$ stock solution used in section $8(250 \mathrm{ppm})$ and ${ }^{207} \mathrm{Bi}$ tracer. The same ${ }^{239} \mathrm{Pu}$ stock solution was used which contained $1.07 \times 10^{-3} \mathrm{~g}$ of ${ }^{241} \mathrm{Pu}$ per gram of ${ }^{239} \mathrm{Pu}$ and $7.66 \times 10^{-4} \mathrm{~g}$ of ${ }^{241} \mathrm{Am}$ per gram of ${ }^{239} \mathrm{Pu}$.

To run through sections 12 and 13 at a lab scale we had to run at a $9.22 \times 10^{-7}$ scale. Since most all of the uranium should be removed after section 8 no uranium was included in these runs. Section 8 was run cold in order to produce a $1.14167 \mathrm{~g}$ of dissolved $\mathrm{BiPO}_{4}$ cake solution (output of section 8C).

In sections 12 and $13 \mathrm{Pu}$ should be oxidized to $\mathrm{Pu}^{+6}$ and remains in solution while the fission products precipitate out with the $\mathrm{BiPO}_{4}$. The oxidants used are $\mathrm{NaBiO}_{3}$, and $\mathrm{Na}_{2} \mathrm{Cr}_{2} \mathrm{O}_{7}$. The Ce- $\mathrm{Zr}$ solution mentioned in Tables 13 and 14 consisted of a solution that contained $5.6 \%$ $\left(\mathrm{NH}_{4}\right)_{2} \mathrm{Ce}\left(\mathrm{NO}_{3}\right)_{2}, 3.6 \% \mathrm{ZrO}\left(\mathrm{NO}_{3}\right)_{2}$ and $6 \% \mathrm{HNO}_{3}$. This Ce- $\mathrm{Zr}$ solution is indicated (in HW$10475 \mathrm{C}$ ) to be a scavenger agent that aids in the precipitation of the byproducts (fission products). Also noted in $\mathrm{HW}-10475 \mathrm{C}$ the presence of the $\mathrm{Ce}-\mathrm{Zr}$ solution also decreases the product $(\mathrm{Pu})$ yield in these steps. The lab scale execution of sections 12 and 13 are summarized in Tables 10-13. 


\begin{tabular}{|c|c|c|}
\hline Reagent & $\begin{array}{l}\text { Weight in } \\
\text { original } \\
\text { document (lb) }\end{array}$ & $\begin{array}{l}\text { Mass or activity } \\
\text { used for lab scale }\end{array}$ \\
\hline $\begin{array}{l}\mathrm{BiPO}_{4} \text { dissolved cake solution } \\
\text { (output of section } 8 \mathrm{C} \text { ) }\end{array}$ & 3250 & $1.14167 \mathrm{~g}$ \\
\hline $\mathrm{H}_{2} \mathrm{O}$ & 2245 & $0.93960 \mathrm{~g}$ \\
\hline${ }^{239} \mathrm{Pu}$ & & $2.9 \mu \mathrm{Ci}$ \\
\hline${ }^{207} \mathrm{Bi}$ & & $0.0139 \mu \mathrm{Ci}$ \\
\hline $\mathrm{NaBiO}_{3} 10 \%$ slurry & 135 & $0.05200 \mathrm{~g}$ \\
\hline \multicolumn{3}{|l|}{ Heated to $50^{\circ} \mathrm{C}$ for $1 \mathrm{hr}$} \\
\hline $\mathrm{Na}_{2} \mathrm{Cr}_{2} \mathrm{O}_{7} 1 \%$ & 550 & $0.23049 \mathrm{~g}$ \\
\hline
\end{tabular}

Table 11. Summary of section 13A First By-Product Precipitation run labeled pg 125 of LRB 60155

\begin{tabular}{|c|c|c|}
\hline Reagent & $\begin{array}{l}\text { Weight in } \\
\text { original } \\
\text { document (lb) }\end{array}$ & $\begin{array}{l}\text { Mass or activity } \\
\text { used for lab scale }\end{array}$ \\
\hline Solution from section 12 & 6420 & $2.98986 \mathrm{~g}$ \\
\hline $\mathrm{H}_{2} \mathrm{O}$ & 13870 & $5.73688 \mathrm{~g}$ \\
\hline $\mathrm{BiONO}_{3} 24 \%, \mathrm{HNO}_{3} 19 \%$ & 140 & $0.07261 \mathrm{~g}$ \\
\hline \multicolumn{3}{|l|}{ Heated to $75^{\circ} \mathrm{C}$ for $1 \mathrm{hr}$} \\
\hline $\mathrm{Na}_{2} \mathrm{Cr}_{2} \mathrm{O}_{7} 1 \%$ & 250 & $0.1552 \mathrm{~g}$ \\
\hline Ce-Zr solution $^{*}$ & 72 & $0.03023 \mathrm{~g}$ \\
\hline \multicolumn{3}{|l|}{ Shake for $10 \mathrm{~min}$} \\
\hline $\mathrm{H}_{3} \mathrm{PO}_{4} 73.5 \%, \mathrm{HNO}_{3} 1.2 \%$ & 267 & $0.10994 \mathrm{~g}$ \\
\hline Shake for $1 \mathrm{hr}$ & & \\
\hline
\end{tabular}

Section $13 \mathrm{~B}$ is the centrifugation step for the solution generated in section 13A. After the $\mathrm{H}_{3} \mathrm{PO}_{4}$ is added to the solution in $13 \mathrm{~A}$ a white precipitate formed. This solution was centrifuged at $4400 \mathrm{rpm}$ for $5 \mathrm{~min}$. The supernate was pulled off and collected in a second centrifuge tube. $200 \mu \mathrm{L}$ of water was added to wash the cake. The cake solution was then centrifuged again at $4400 \mathrm{rpm}$ for $5 \mathrm{~min}$. The wash water will pulled off and added to the second centrifuge tube along with the supernate. The filtrate was then used in section $13 \mathrm{C}$. 


\begin{tabular}{|l|l|r|}
\hline $\begin{array}{l}\text { Table 12. Summary of section 13C First By-Product Precipitation run } \\
\text { labeled pg } 125 \text { of LRB 60155 }\end{array}$ & $\begin{array}{l}\text { Weight in } \\
\text { original } \\
\text { document (lb) }\end{array}$ & $\begin{array}{l}\text { Mass or activity } \\
\text { used for lab scale }\end{array}$ \\
\hline Reagent & 22380 & $8.90483 \mathrm{~g}$ \\
\hline Filtrate from section 13B & 120 & $0.05252 \mathrm{~g}$ \\
\hline $\mathrm{NaBiO}_{3} 10 \%$ slurry & 75 & $0.03276 \mathrm{~g}$ \\
\hline Ce-Zr solution & & \\
\hline Shake for $1 \mathrm{hr}$ & & \\
\hline
\end{tabular}

Section $13 \mathrm{D}$ is a centrifugation step where the left over $\mathrm{NaBiO}_{3}$ solid is separated out. The solution form 13C was centrifuged at $4400 \mathrm{rpm}$ for $5 \mathrm{~min}$. The supernate was transferred to a $20 \mathrm{~mL}$ scintillation vial. The solid cake was washed with $175 \mu \mathrm{L}$ of $\mathrm{H}_{2} \mathrm{O}$ and then centrifuged again at $4400 \mathrm{rpm}$ for $5 \mathrm{~min}$. The wash water was added to the $20 \mathrm{~mL}$ scintillation vial with the supernate. The cake was carried on to section 13E and the supernate and wash water were diluted to a $10 \mathrm{~mL}$ volume with $\mathrm{H}_{2} \mathrm{O}$ and submitted for counting.

Section 13E outlines the dissolution of the cake generated in sections 13B and 13E. This cake is supposed to contain the fission and be devoid of plutonium. The dissolution procedure is summarized in Table 13.

\begin{tabular}{|l|r|r|}
\hline $\begin{array}{l}\text { Table 13. Summary of section 13E First By-Product Precipitation run } \\
\text { labeled pg } 125 \text { of LRB } 60155\end{array}$ & $\begin{array}{l}\text { Weight in } \\
\text { original } \\
\text { document (lb) }\end{array}$ & $\begin{array}{l}\text { Mass or activity } \\
\text { used for lab scale }\end{array}$ \\
\hline Reagent & 360 & $0.09207 \mathrm{~g}$ \\
\hline Cake from 13D & 1400 & $0.61996 \mathrm{~g}$ \\
\hline $\mathrm{HNO}_{3} 60 \%$ & & $0.04677 \mathrm{~g}$ \\
\hline Shake for 30 min & 100 & \\
\hline $\mathrm{H}_{2} \mathrm{O}_{2} 27.5 \%$ & & $0.20715 \mathrm{~g}$ \\
\hline $\mathrm{Added} \mathrm{cake} \mathrm{from} \mathrm{section} \mathrm{13B}^{2}$ & 500 & \\
\hline $\mathrm{Na}_{2} \mathrm{Cr}_{2} \mathrm{O}_{7}$ & &
\end{tabular}

The dissolved cake solution from section $13 \mathrm{E}$ was transferred to a $20 \mathrm{~mL}$ scintillation vial. The solution was diluted to a $10 \mathrm{~mL}$ volume and then submitted for counting. The results from gamma counting the dissolved cake solution from $13 \mathrm{E}$ and the supernate from section $13 \mathrm{C}$ are shown in Table 14. 
Table 14. Results from gamma spectroscopy of the two fractions collected from section 13 First By-Product Precipitation run labeled pg 125 of LRB 60155. The percent errors associated with the counting statistics are in parenthesis.

\begin{tabular}{|r|r|r|}
\hline & \multicolumn{2}{|l|}{ \% left in solution after } \\
Isotope & \% in cake & \multicolumn{2}{l|}{\begin{tabular}{l} 
precipitation \\
\hline${ }^{207} \mathrm{Bi}$
\end{tabular}} & $99.82(2.76)$ & $0.1801(2.12)$ \\
\hline${ }^{239} \mathrm{Pu}$ & $42.20(1.04)$ & $57.80(1.04)$ \\
\hline${ }^{241} \mathrm{Am}$ & $6.202(5.26)$ & $93.80(4.75)$ \\
\hline${ }^{241} \mathrm{Pu}$ & $42.59( \pm 2.90)$ & $57.41( \pm 5.03)$ \\
\hline
\end{tabular}

The results of this run were not quite as expected. The $\mathrm{Pu}$ was supposed to stay in solution but in this run we got a nearly 50:50 split. This odd result could have been caused by insufficient quantities of oxidants added.

\section{FUTURE}

Efforts are underway to rectify the unexpected results from the Lab Scale runs of Sections 12 "Preparation For First By-Product Precipitation" and 13 "First By-Product Precipitation". Once these issues are worked out, lab scale replication of the remainder of the steps in the Bismuth Phosphate process will continue. In addition, chemical equilibrium models are being developed at PNNL to simulate the Bismuth Phosphate process. These models use a Newton-Raphson numerical method to solve for a series of nonlinear equations describing equilibrium within the system. These models require a database of equilibrium constants describing all important chemical reactions within the system and calculate activity coefficients using Debye-Huckel or virial approaches[4], depending upon the ionic strength of the system being modeled. In a few instances, unique samples of opportunity with defined pedigree to historic recycling efforts at Hanford have been identified and analyzed for their elemental composition [5]. Analyses of these samples provide a realistic picture of contaminant patterns at certain points within the industrial-scale process that can be compared to results from lab-scale and model process replication efforts.

\section{ACKNOWLEDGEMENTS}

This research was sponsored by the National Technical Nuclear Forensics Center within the Department of Homeland Security and conducted at the U.S. Department of Energy's Pacific Northwest National Laboratory, which is operated for DOE by Battelle under Contract DEAC05-76RL1830. Additional support was received from Nuclear Forensics Fellowship Program.

\section{REFERENCES}

1. BRIGGS, J.D. Historical time line and information about the Hanford site, report: PNNL-13524, Pacific Northwest National Laboratory, Richland, 2001.

2. http://www.cfo.doe.gov/me70/manhattan/seaborg_plutonium.htm

3. Revised Hanford Separation Process Flow Sheet, October 5, 1944, DUH-1687. 
4. BETHKE, C.M. Geochemical reaction modeling, Oxford University Press, New York, NY, 1996.

5. PARKHURST, D.L.: User's guide to PHREEQC, a computer model for speciation, reaction-path, advective-transport and inverse geochemical calculations. U.S. Geological Survey Water-Resources Investigations Report 99-4259, p.143, 1999.

6. BALL, J.W., NORDSTROM, D.K., WATEQ4F--User's manual with revised thermodynamic data base and test cases for calculating speciation of major, trace and redox elements in natural waters, U.S. Geological Survey Open-File Report 90-129, p. $185,1991$.

7. SCHWANTES, J.M. M. DOUGLAS,S. BONDE, J.D. BRIGGS, O.T. FARMER, L. GREENWOOD, E. LEPEL, C. ORTON, J. WACKER, AND A. LUKSIC, Nuclear Archeology in a Bottle: Evidence of Pre-Trinity U.S. Weapons Activities from a Waste Burial Site, Feature in Analytical Chemistry, 81, 4, 1297, 2009.

8. K.R. MACNEILL, "Recycling waste streams using glass making activities" Proceedings of Contaminated Land: Policy, Regulation, and Technology, IBC Technical Services, London, UK, (1991). 